\title{
Molecular characterization of non-aureus Staphylococcus spp. from heifer intramammary infections and body sites
}

\author{
P. R. F. Adkins, ${ }^{*}$ S. Dufour,† J. N. Spain,ł M. J. Calcutt,§ T. J. Reilly,§\# G. C. Stewart,§॥ and J. R. Middleton*1 \\ ${ }^{*}$ Department of Veterinary Medicine and Surgery, University of Missouri, Columbia 65211 \\ †Department of Pathology and Microbiology, University of Montreal, Quebec, Canada J2S 2M2 \\ ‡Department of Animal Science, \\ §Department of Veterinary Pathobiology, \\ \#Veterinary Medical Diagnostic Laboratory, Department of Veterinary Pathobiology, and \\ IIBond Life Sciences Center, University of Missouri, Columbia 65211
}

\begin{abstract}
The purpose of this study was to investigate nonaureus Staphylococcus spp. intramammary infections (IMI) in periparturient heifers and determine the relationship of precalving body site isolation with precalving IMI and postcalving IMI using molecular speciation and strain-typing methods. Primiparous heifers were enrolled at approximately $14 \mathrm{~d}$ before expected calving date. Precalving mammary quarter secretions and body site swabbing samples (teat skin, inguinal skin, muzzle, and perineum) were collected. Postcalving, mammary quarter milk samples were collected for culture and somatic cell counting. Precalving body site samples were cultured, and up to 10 staphylococcal colonies were saved for characterization. Staphylococcal isolates were speciated using matrix-assisted laser/desorption ionization time-of-flight mass spectrometry or sequencing of rpoB or tuf. Pulsed-field gel electrophoresis was used to strain type a subset of isolates. Overall, Staphylococcus chromogenes, Staphylococcus agnetis, and Staphylococcus simulans were the most common species identified in precalving mammary secretions, whereas $S$. chromogenes, Staphylococcus xylosus, and S. agnetis were the most common species found in postcalving milk samples. The most common species identified from body site samples were $S$. chromogenes, $S$. xylosus, and Staphylococcus haemolyticus. Mammary quarters that had a precalving mammary secretion that was culture positive for S. agnetis, S. chromogenes, or Staphylococcus devriesei had increased odds of having an IMI with the same species postcalving. A S. chromogenes IMI postcalving was associated with higher somatic cell count when compared with postcalving culture-
\end{abstract}

Received September 27, 2017.

Accepted January 24, 2018.

${ }^{1}$ Corresponding author: middletonjr@missouri.edu negative quarters. Among heifers identified with a non-aureus Staphylococcus spp. IMI either precalving or postcalving, heifers that had S. agnetis or S. chromogenes isolated from their teat skin had increased odds of having the same species found in their precalving mammary secretions, and heifers with $S$. chromogenes, S. simulans, and S. xylosus isolated from their teat skin precalving were at increased odds of having an IMI with the same species postcalving. Overall, $44 \%$ of all heifers with a $S$. chromogenes IMI around the time of parturition had the same strain isolated from a body site. Based on pulsed-field gel electrophoresis, a high level of strain diversity was found.

Key words: heifer, non-aureus Staphylococcus spp., matrix-assisted laser desorption/ionization time-offlight mass spectrometry, pulsed-field gel electrophoresis

\section{INTRODUCTION}

Non-aureus Staphylococcus spp. (NAS) are the most common cause of IMI in heifers both before and after calving (Fox et al., 1995; Fox, 2009; De Vliegher et al., 2012). The percentage of NAS-infected quarters in heifers postcalving is approximately 35 to $37 \%$ (RajalaSchultz et al., 2009; Piepers et al., 2010; De Visscher et al., 2016a). When using molecular techniques to speciate NAS, the most common species identified in heifers include Staphylococcus chromogenes, Staphylococcus simulans, and Staphylococcus xylosus (De Visscher et al., 2016a), which are considered among the most important NAS species as they have a more substantial effect on udder health and milk quality than other NAS species (Supré et al., 2011; Fry et al., 2014). Mammary quarters infected at parturition with $S$. chromogenes, $S$. simulans, or $S$. xylosus can have a geometric mean SCC above 400,000 cells/mL (De Visscher et al., 2016a). Increased SCC early in the first lactation can have a lasting negative effect on milk quality and production, including elevations in first-lactation SCC (De Vliegher et al., 2004a) and decreased first-lactation milk produc- 
tion (Coffey et al., 1986; De Vliegher et al., 2005b). Furthermore, an increased SCC between 5 and 30 DIM of the first lactation can negatively affect lifetime milk yield (Archer et al., 2013). In general, mastitis in heifers has also been associated with increased culling, with each unit increase in the LnSCC in early lactation being associated with an 11\% increase in culling hazard (De Vliegher et al., 2005a).

Staphylococci are part of the normal skin flora of animals (Devriese and De Keyser, 1980; Devriese et al., 1985) and have been isolated from different body sites of cows and heifers and from the dairy environment (White et al., 1989; Taponen et al., 2008; Piessens et al., 2011). With regard to isolation of NAS species from body sites, teat skin has been the primary focus of most studies (De Vliegher et al., 2003; Braem et al., 2013; De Visscher et al., 2016b). Studies to date report that $S$. chromogenes, followed by Staphylococcus haemolyticus, Staphylococcus devriesei, and Staphylococcus equorum, are the main NAS species isolated from teat ends of pregnant heifers (De Visscher et al., 2016b). Depending on the study, 20 to $62 \%$ of heifers harbor S. chromogenes on the teat skin (White et al., 1989; De Visscher et al., 2016b). Moreover, isolation of $S$. chromogenes from the teat end increases the likelihood of $S$. chromogenes IMI in the corresponding quarter at parturition (De Visscher et al., 2016a), which is similar to Staphylococcus aureus (Roberson et al., 1994). Although some research points to the negative effects of isolation of S. chromogenes from the teat end and its relationship to IMI, other studies have found a potential protective effect, as some strains display antibacterial activities in vitro (De Vliegher et al., 2004b; Braem et al., 2014), and heifer quarters with precalving isolation of $S$. chromogenes from the teat end had SCC $<200,000$ cells/mL in early lactation (De Vliegher et al., 2003).

Although ample evidence shows that some of the most important NAS species can be found on the teat end and in the mammary gland of early-lactation heifers, little work has been done to strain type NAS species identified on body sites of precalving heifers to determine whether the same strain is found in the mammary gland either before or after calving. Furthermore, little work has been done to characterize NAS species isolated from body sites other than the teat end and the relationship of such isolation to IMI. One study (White et al., 1989) described isolation of NAS species from body sites other than the teat end; however, that study did not explore the relationship between body site isolation and IMI and used phenotypic methods for speciation. Phenotypic speciation may lead to misclassification of some NAS species based on recent evidence on the poor typeability of phenotypic methods (Zadoks and Watts, 2009). Therefore, the purpose of this study was to investigate NAS IMI in periparturient heifers and determine the relationship of body site isolation, precalving NAS IMI, and postcalving NAS IMI using molecular speciation and pulsed-field gel electrophoresis (PFGE) strain typing.

\section{MATERIALS AND METHODS}

\section{Herd and Heifer Selection}

Late-gestation heifers $(\mathrm{n}=100)$, including both Guernsey $(\mathrm{n}=9)$ and Holstein $(\mathrm{n}=91)$ breeds, at the University of Missouri Foremost Dairy Research Center (Columbia) were enrolled between April 2014 and April 2015. Heifers were enrolled in the study at approximately $14 \mathrm{~d}$ before expected calving date. During the study, the farm milked a median number of 179 (range: 171-193) Holsteins and 26 (range: 25-28) Guernsey cows, had a geometric mean bulk tank SCC of 206,000 cell $/ \mathrm{mL}$, and had an average $305-\mathrm{d}$ milk production of $10,844 \mathrm{~kg}$. All heifers included in the study were raised on the farm. Cows and heifers on the farm calved yearround with the exception of a planned reduction in calving from July to September to avoid calving during peak heat and humidity. The study was approved by the University of Missouri Animal Care and Use Committee (protocol no. 7815).

\section{Sample Collection}

Precalving mammary quarter secretions and postcalving mammary quarter milk samples were aseptically collected from the cohort of heifers. Prior to sample collection, teats were treated with a germicidal teat dip, hand stripped, dried with an individual towel, and then scrubbed with a cotton pad soaked in $70 \%$ isopropyl alcohol. Precalving secretion samples were collected approximately $14 \mathrm{~d}$ before expected calving date. All precalving mammary quarter secretion samples were taken after body site swabbing samples had been collected. In all cases, the person taking the samples wore disposal latex or nitrile gloves, and gloves were changed between animals. Postcalving mammary quarter foremilk samples were collected twice within the first $10 \mathrm{~d}$ of lactation for bacterial culture and somatic cell counting. Samples were collected twice weekly, with each sample collection being 3 to $4 \mathrm{~d}$ apart. Heifers were not sampled until they were at least 3 DIM. The median DIM for the first sample was $4 \mathrm{~d}$ (range: $3-7 \mathrm{~d}$ ), and the median DIM for the second sample was $8 \mathrm{~d}$ (range: 6-10 d). All samples were chilled on ice for transport to the laboratory. Samples for bacterial culture were stored at $-20^{\circ} \mathrm{C}$ until bacteriological examination was performed (median storage time: 32 d; range: 1-134 
d). Milk samples for SCC enumeration were placed in vials containing a 2-bromo-2-nitropropane-1,3-diol preservative tablet (Broad Spectrum Microtabs II, D\&F Control Systems Inc., Dublin, CA), stored at $4^{\circ} \mathrm{C}$, and shipped once weekly to a commercial laboratory (MidSouth Dairy Records, Springfield, MO).

Body site swabbing samples were collected once at the precalving sampling time point. All heifers were restrained in a chute for sample collection. Gloves were worn at all times and were changed between each sample collected. Prior to sample collection, visible debris was removed with a dry disposable towel. Body site swabbing samples were collected by rubbing a dry sterilized electrostatic duster (Swiffers; Procter \& Gamble, Cincinnati, OH; Hoet et al., 2011; van Balen et al., 2013; Adkins et al., 2018) over the entire surface of each site. A total of 4 body site samples were collected and included 1 composite sample of all 4 teats, 1 composite sample of both inguinal regions, 1 muzzle sample (including the muzzle surface and the rostral aspect of the each nostril), and 1 sample from the perineum. Body sites selected for sampling were based on sites previously examined for $S$. aureus (Roberson et al., 1994; Middleton et al., 2002b). All body site swabbing samples were placed in individual sterile whirl pack bags (Nasco, Fort Atkinson, WI), sealed, chilled on ice, transported to the laboratory, and processed the same day.

\section{Laboratory Procedures}

Precalving mammary secretions and postcalving milk samples were thawed at room temperature $\left(22^{\circ} \mathrm{C}\right)$, and $10 \mu \mathrm{L}$ of the respective samples was evenly spread onto half a Columbia blood agar (CBA) plate and incubated at $37^{\circ} \mathrm{C}$ for $24 \mathrm{~h}$, followed by $24 \mathrm{~h}$ at room temperature $\left(22^{\circ} \mathrm{C}\right.$; Roberson et al., 1994). Plates were read at 24 and $48 \mathrm{~h}$. Primary bacterial identification was determined according to the National Mastitis Council guidelines (Middleton et al., 2017). Briefly, the potassium hydroxide gelation test was used to differentiate gram-negative from gram-positive bacteria. Staphylococcal species were presumptively identified based on colony morphology, a positive catalase reaction, and results of the coagulase test (Middleton et al., 2017). All isolates presumed to be staphylococcal species were stored in phosphate-buffered glycerol at $-80^{\circ} \mathrm{C}$ until further processing. Milk SCC was determined at a commercial laboratory (Mid-South Dairy Records) using an automated cell counter (Somacount 300, Bentley Instruments, Chaska, MN).

Body site swabbing samples were mixed with 10 $\mathrm{mL}$ of sterile saline in the original whirl pack bag and agitated with a vortex (Vortex-Genie 2; Scientific Industries Inc., Bohemia, NY), and $50 \mu \mathrm{L}$ of the resultant solution was plated on mannitol salt agar. Plates were incubated at $37^{\circ} \mathrm{C}$ for $24 \mathrm{~h}$. At $24 \mathrm{~h}$, mannitol salt agar plates were read and up to 10 presumptively identified staphylococcal colonies, including at least 1 of each morphologically distinct colony type, were subcultured onto CBA. On primary cultures yielding $>10$ colonies, when some or all of the colonies were morphologically similar, multiple colonies of the same morphology were randomly selected to make up the 10 characterized colonies. On primary cultures yielding $\leq 10$ colonies, all colonies were subcultured and further characterized. All isolates were stored in phosphate-buffered glycerol at $-80^{\circ} \mathrm{C}$ until further processing. All staphylococcal isolates from pre- or postcalving IMI were speciated as described below; however, because the overall objective was to determine the relationship between body site isolation and pre- or postcalving IMI, only body site isolates that originated from heifers with a pre- or postcalving staphylococcal IMI were subjected to further speciation.

All staphylococcal isolates that were subjected to speciation were initially speciated using matrix-assisted laser desorption/ionization time-of-flight (MALDITOF) MS (Tomazi et al., 2014; Cameron et al., 2017, 2018). Samples were processed on a MALDI-TOF mass spectrometer (Microflex, Bruker Daltonics, Bremen, Germany) using proprietary software (Flex Control, Bruker Daltonics). The MALDI-TOF target plate was prepared using the plate extraction method (Bruker Daltonics). The plate extraction method was performed by spotting 1 colony of each bacterial isolate on the MALDI-TOF target plate in duplicate and overlaying each spot with $1 \mu \mathrm{L}$ of $70 \%$ formic acid. Once dried, the spot was overlaid with $1 \mu \mathrm{L}$ of matrix solution consisting of $\alpha$-cyano-4-hydroxycinnamic acid diluted in a solution of $50 \%$ acetonitrile and $2.5 \%$ trifluoroacetic acid. A bacterial test standard (Bruker Daltonics) was used to calibrate the instrument before running test samples. Peaks produced by each sample were compared with entries in the manufacturer's database and the University of Missouri laboratory custom database (see below) using the standard parameters of the pattern-matching algorithm. The MALDI-TOF manufacturer's identification cut-off value for species-level identification (a score of $\geq 2$ on at least 1 of the duplicate samples) was used to make a diagnosis. Any score $<2$ was classified as inconclusive for species identification.

An in-house validation of the MALDI-TOF was performed by speciating the first 770 isolates from the study by comparing the results of the MALDI-TOF analysis with housekeeping gene sequences (see below). The 770 
isolates represented 17 species (Table 1). When a score of $\geq 2$ was obtained, MALDI-TOF correctly identified $73.4 \%$ of the isolates overall and a range of 0 to $100 \%$ of isolates within each species. Three of the commonly isolated NAS species (Staphylococcus agnetis, S. devriesei, and $S$. haemolyticus) had a low identification accuracy $(<74 \%)$ either because they were not included in the manufacturer's database (S. agnetis and S. devriesei) or because the included database isolate yielded a poor identification accuracy for the tested bovine isolates (S. haemolyticus). Therefore, for each of these 3 species, a single representative isolate, obtained from the authors' isolate collection, was added to the University of Missouri laboratory custom database (Cameron et al., 2018). All 3 isolates were added to the custom database according to the manufacturer's instructions in which 100 known isolates of a given species that had previously been identified using rpoB (Drancourt and Raoult, 2002) or tuf (Hwang et al., 2011) sequencing were run against the reference isolates added to the custom database to verify accurate identification. After the creation of the custom database, MALDI-TOF accurately identified $96.1 \%$ of the 770 isolates overall, with a range of 0 to $100 \%$ of isolates within each species (Table 1). Identification of $S$. devriesei with the manufacturer's database was $0 \%$ but was $100 \%$ with the custom library. Identification of $S$. haemolyticus was $66.9 \%$ using the manufacturer's database but was 95.3\% with the custom library (Table 1 ).

For MALDI-TOF validation, and for all isolates where MALDI-TOF yielded inconclusive results, isolates were speciated using PCR amplification and subsequent sequencing of a portion of either rроB or tuf. Briefly, isolates were cultured on $\mathrm{CBA}$ at $37^{\circ} \mathrm{C}$ for $24 \mathrm{~h}$ and a single representative colony was inoculated into $100 \mu \mathrm{L}$ of $1 \times$ Tris-EDTA (Promega, Madison, WI) for lysate preparation. Standard PCR, with the addition of an initial denaturation step of $15 \mathrm{~min}$ at $94^{\circ} \mathrm{C}$, was performed to amplify a portion of $r p o B$ (Drancourt and Raoult, 2002) or tuf (Hwang et al., 2011). The resultant PCR products were purified using a commercial kit (Invitrogen, Carlsbad, CA) and submitted to the University of Missouri DNA Core Facility for gene sequencing. Sequences were compared with the GenBank database using the publicly available nucleotideBLAST algorithm (https://blast.ncbi.nlm.nih.gov). For rроB analysis, species identity was confirmed when the sequence had $\geq 97 \%$ identity with a single species in the GenBank database (Mellmann et al., 2006). For tuf analysis, species were confirmed when sequence

Table 1. Performance of matrix-assisted laser desorption/ionization time-of-flight (MALDI-TOF) for the identification and discrimination of non-aureus Staphylococcus (NAS) isolates of bovine origin ${ }^{1}$

\begin{tabular}{|c|c|c|c|c|c|}
\hline \multirow[b]{2}{*}{ NAS species } & \multirow{2}{*}{$\frac{\text { Final ID }}{\text { Total }}$} & \multicolumn{2}{|c|}{ MALDI ID } & \multicolumn{2}{|c|}{$\begin{array}{l}\text { MALDI ID with } \\
\text { custom database }\end{array}$} \\
\hline & & No. & $\mathrm{CID} \%^{2}$ & No. & CID $\%$ \\
\hline S. agnetis/hyicus ${ }^{3}$ & 19 & 14 & 73.6 & 19 & 100 \\
\hline S. arlettae & 5 & 0 & 0.0 & 0 & 0.0 \\
\hline S. auricularis & 6 & 1 & 16.7 & 1 & 16.7 \\
\hline S. chromogenes & 359 & 359 & 100 & 359 & 100 \\
\hline S. cohnii & 1 & 0 & 0.0 & 0 & 0.0 \\
\hline S. devriesei & 122 & 0 & 0.0 & 122 & 100 \\
\hline S. equorum & 3 & 3 & 100 & 3 & 100 \\
\hline S. gallinarum & 1 & 0 & 0.0 & 0 & 0.0 \\
\hline S. haemolyticus & 169 & 113 & 66.9 & 161 & 95.3 \\
\hline S. kloosii & 1 & 1 & 100 & 1 & 100 \\
\hline S. nepalensis & 1 & 1 & 100 & 1 & 100 \\
\hline S. pulvereri & 9 & 0 & 0.0 & 0 & 0.0 \\
\hline S. saprophyticus & 6 & 6 & 100 & 6 & 100 \\
\hline S. sciuri & 7 & 6 & 85.7 & 6 & 85.7 \\
\hline S. simulans & 15 & 15 & 100 & 15 & 100 \\
\hline S. xylosus & 46 & 46 & 100 & 46 & 100 \\
\hline Total & 770 & 565 & 73.4 & 740 & 96.1 \\
\hline
\end{tabular}

${ }^{1}$ The table includes results with both the manufacturer's database (Bruker Daltonics, Bremen, Germany; column labeled MALDI ID) and the manufacturer's database plus the University of Missouri (Columbia) laboratory custom database (column labeled MALDI ID with custom database).

${ }^{2} \mathrm{CID} \%=$ percentage correctly identified.

${ }^{3}$ MALDI-TOF was unable to differentiate $S$. agnetis from $S$. hyicus and gives a score of $\geq 2$ for both. Hence, when either species is identified by MALDI-TOF, supplemental testing will be required to differentiate the 2 species. Percentage correctly identified in the table reflects the ability of MALDI-TOF to at least classify the isolate as S. agnetis or S. hyicus. 
identity was $\geq 98.0 \%$ with $>0.8 \%$ separation between species (Hwang et al., 2011). Any isolate identified as S. agnetis or Staphylococcus hyicus by MALDI-TOF was speciated using the aroD multiplex PCR (Adkins et al., 2017) because MALDI-TOF cannot differentiate these 2 species. Isolates that could not be speciated by MALDI-TOF, housekeeping gene sequencing, or the aro $D$ gene multiplex PCR were designated as unidentified NAS.

Heifers that had a precalving mammary quarter secretion or postcalving mammary quarter milk sample and a body site sample with isolates of the same species identified within heifer were selected for strain typing by PFGE. All body site, mammary secretion, and milk sample isolates within heifer were strain typed. Because the objective was to identify all strains within a given species, all isolates of the same species from a given body site or IMI were strain typed. Hence, all replicates within heifer were studied. For S. agnetis, S. devriesei, S. haemolyticus, Staphylococcus sciuri, S. simulans, and S. xylosus, all heifers with body site isolates and an IMI were studied. Due to the high prevalence of heifers with body site isolates and an IMI with $S$. chromogenes and the cost of PFGE, only a random sample of heifers $(60 \%)$ with a $S$. chromogenes IMI were studied with strain typing. A total of $60 \%$ of heifers with a $S$. chromogenes IMI were selected because $S$. chromogenes IMI represented $60 \%$ of all quarters with a NAS IMI that had a corresponding body site sample of the same species identified. Heifers with $S$. chromogenes body site isolates and an IMI were randomly selected using the Microsoft Excel (2013 version; Microsoft Corp., Redmond, WA) random number generator. All strain typing was performed using PFGE as previously described (Middleton et al., 2002a). Briefly, SmaI (Invitrogen) digests of staphylococcal DNA were separated by PFGE in a 1\% agarose gel (pulsed field certified agarose, Bio-Rad, Hercules, CA) immersed in $0.5 \%$ Tris-boric acid-EDTA) buffer at $15^{\circ} \mathrm{C}$ for $20 \mathrm{~h}$ at $6 \mathrm{~V} / \mathrm{cm}$ with a 5 - to 50-s pulse time on a Chef DRIII PFGE machine (BioRad). Salmonella Braenderup ATCC BAA-664 was used as a molecular weight size standard and was digested using $\mathrm{Xba \textrm {I }}$ (Invitrogen). Standards were included in the first, middle, and last lane of each gel. Completed gels were stained with ethidium bromide and photographed using UV transillumination. Images were analyzed using Bionumerics 7.5 (Applied Maths, Sint-Martens-Latem, Belgium) using Dice similarity coefficient and an unweighted pair group method with arithmetic mean (UPGMA) dendrogram type. Tolerance settings included optimization at $0.5 \%$ and position tolerance at $1.0 \%$. Strain types were determined by using a threshold cut point of $100 \%$ similarity.

\section{Defining IMI Status}

A mammary quarter was defined as having a precalving IMI with a given NAS species when that species was recovered from the single precalving mammary quarter secretion sample at a concentration $\geq 100 \mathrm{cfu} / \mathrm{mL}$ ( 1 colony per $10 \mu \mathrm{L}$ of inoculum). A mammary quarter was defined as having a postcalving IMI with a given NAS species if that species was recovered from one or both (i.e., parallel interpretation) postcalving quarter milk samples at a concentration $\geq 100 \mathrm{cfu} / \mathrm{mL}$ (Dohoo et al., 2011a,b). A mammary quarter IMI was defined as a mixed infection when 2 different bacterial colony types were present and contaminated when 3 or more different bacterial colony types were present.

\section{Statistical Analyses}

Precalving IMI and Its Relationship to Postcalving IMI and Milk SCS. First, the association between precalving quarter NAS IMI status and postcalving NAS IMI status was investigated. To achieve this, generalized mixed models using a logit link function and with heifer treated as random intercept were used. The outcomes in these models were always whether a quarter was infected by a given NAS species at postcalving samplings, and the only fixed predictor was the precalving quarter NAS IMI status. Different models were therefore used for each of the NAS IMI species recovered from the postcalving quarter milk samples. Models were run using the GLIMMIX procedure and using a Gauss-Hermite quadrature approximation method (i.e., method = quad) in SAS 9.4 (SAS Institute Inc., Cary, NC).

Then, the effect of precalving and postcalving quarter NAS IMI statuses on postcalving SCS were investigated. To achieve this, 2 linear mixed models (i.e., one for precalving and one for postcalving quarter NAS IMI status) with heifer random intercepts were used. In these models, the precalving NAS IMI status or the postcalving quarter NAS IMI status (e.g., no NAS IMI, S. agnetis IMI, Staphylococcus auricularis, and so on) was used as sole predictor of postcalving SCS. In these models, the natural logarithm of the SCS observed on the second postcalving sampling was used as the outcome. The second sampling was used because the maximum sensitivity and specificity for detecting IMI with SCC is reached when samples are evaluated $\geq 5 \mathrm{~d}$ postcalving (Sargeant et al., 2001) and the first postcalving samples were collected before d 5 . The natural logarithm of this second SCS measurement rather than the raw SCS was used to meet the assumptions of normality and homoscedasticity of the residuals. Mod- 
els were run using the MIXED procedure of SAS 9.4. Assumptions of normality and homoscedasticity were verified using quantile plots of the residuals and plots of predicted values against residuals, respectively.

Body Site Isolation and Its Relationship to Pre- or Postcalving IMI. The association between precalving isolation of a given NAS species from a given body site and precalving and postcalving quarter NAS IMI status for that NAS species was investigated. To achieve this, generalized mixed models using a logit link function and with heifer treated as random intercept were used. A series of models investigated whether body site isolation would influence precalving NAS IMI status, and another series investigated the effect on postcalving NAS IMI status. Again, different models were used for each of the NAS IMI species recovered from the post- and precalving quarter milk samples. Fixed predictors investigated were inguinal, teat, muzzle, and perineum region NAS isolation status. These predictors were included one at a time in the model (i.e., unconditional associations). Again, models were run using the GLIMMIX procedure and using a Gauss-Hermite quadrature approximation method in SAS 9.4. Statistically significant results for all analyses were defined as those yielding a $P$-value $<0.05$.
RESULTS

\section{Precalving IMI and Its Relationship to Postcalving IMI and Milk SCS}

All 100 heifers completed the study. Overall, $83 \%$ ( $\mathrm{n}=$ $83)$ of heifers and $30 \%(122 / 400)$ of mammary quarters had a NAS species identified in a precalving secretion or milk sample from at least 1 mammary quarter at $\geq 1$ of the sample time points (precalving or postcalving; sample 1 or sample 2$)$, whereas $17 \%(\mathrm{n}=17)$ of heifers were NAS culture negative at all time points. Among the 100 heifers, $23 \%(92 / 400)$ of precalving mammary quarter secretions from 47 heifers, $16 \%(62 / 400)$ of postcalving quarter milk samples from 41 heifers at sample 1 , and $13 \%(52 / 400)$ of postcalving quarter milk samples from 38 heifers at sample 2 had a NAS species isolated. At the species level, 17 different NAS species were identified among all the quarter mammary secretions and milk samples. The most common NAS species identified in precalving mammary secretion samples in order of prevalence were $S$. chromogenes, S. agnetis, $S$. simulans, and $S$. devriesei (Table 2). In postcalving milk samples, the most common NAS species identified was S. chromogenes, followed by S. xylosus, S. agnetis, and

Table 2. Proportion of precalving and postcalving mammary quarters and of body sites positive for various non-aureus Staphylococcus (NAS) species from heifers identified with a NAS IMI at least once in 1 precalving mammary secretion sample or 1 of the 2 postcalving milk samples

\begin{tabular}{|c|c|c|c|c|c|c|}
\hline \multirow[b]{2}{*}{ NAS species } & \multicolumn{2}{|c|}{ No. of quarters (\%) } & \multicolumn{4}{|c|}{ No. of body sites (\%) } \\
\hline & Precalving $^{1}$ & Postcalving $^{2}$ & Inguinal region & Teat skin & Muzzle & Perineum \\
\hline S. chromogenes & $59(14.8)$ & $51(12.8)$ & $67(80.7)$ & $49(59.0)$ & $24(28.9)$ & $42(50.6)$ \\
\hline S. agnetis & $12(3.0)$ & $5(1.3)$ & $4(4.8)$ & $4(4.8)$ & $0(0)$ & $0(0)$ \\
\hline S. simulans & $6(1.5)$ & $5(1.3)$ & $4(4.8)$ & $4(4.8)$ & $0(0)$ & $0(0)$ \\
\hline S. devriesei & $6(1.5)$ & $2(0.5)$ & $22(26.5)$ & $35(42.2)$ & $3(3.6)$ & $6(7.2)$ \\
\hline S. haemolyticus & $4(1.0)$ & $3(0.8)$ & $35(42.2)$ & $36(43.4)$ & $14(16.9)$ & $20(24.1)$ \\
\hline S. xylosus & $2(0.5)$ & $6(1.5)$ & $28(33.7)$ & $25(30.1)$ & $39(47.0)$ & $17(20.5)$ \\
\hline S. epidermidis & $1(0.3)$ & $1(0.3)$ & $0(0)$ & $0(0)$ & $0(0)$ & $0(0)$ \\
\hline S. hominis & $1(0.3)$ & $1(0.3)$ & $0(0)$ & $0(0)$ & $0(0)$ & $0(0)$ \\
\hline S. warneri & $1(0.3)$ & $1(0.3)$ & $0(0)$ & $0(0)$ & $0(0)$ & $0(0)$ \\
\hline S. gallinarum & $1(0.3)$ & $1(0.3)$ & $0(0)$ & $0(0)$ & $0(0)$ & $0(0)$ \\
\hline S. equorum & $0(0)$ & $2(0.5)$ & $3(3.6)$ & $9(10.8)$ & $33(39.8)$ & $12(14.5)$ \\
\hline S. sciuri & $0(0)$ & $1(0.3)$ & $13(15.7)$ & $24(28.9)$ & $32(38.6)$ & $7(8.4)$ \\
\hline S. lentus & $0(0)$ & $1(0.3)$ & $3(3.6)$ & $4(4.8)$ & $5(6.0)$ & $1(1.2)$ \\
\hline S. vitulinus & $0(0)$ & $1(0.3)$ & $3(3.6)$ & $4(4.8)$ & $4(4.8)$ & $1(1.2)$ \\
\hline S. auricularis & $0(0)$ & $1(0.3)$ & $1(1.2)$ & $0(0)$ & $2(2.4)$ & $1(1.2)$ \\
\hline S. arlettae & $0(0)$ & $1(0.3)$ & $0(0)$ & $6(7.2)$ & $7(8.4)$ & $2(2.4)$ \\
\hline S. pasteuri & $0(0)$ & $1(0.3)$ & $0(0)$ & $0(0.0)$ & $0(0)$ & $0(0)$ \\
\hline S. saprophyticus & $0(0)$ & $0(0)$ & $6(7.2)$ & $6(7.2)$ & $23(27.7)$ & $7(8.4)$ \\
\hline S. nepalensis & $0(0)$ & $0(0)$ & $3(3.6)$ & $1(1.2)$ & $9(10.8)$ & $2(2.4)$ \\
\hline S. cohnii & $0(0)$ & $0(0)$ & $1(1.2)$ & $1(1.2)$ & $13(15.7)$ & $10(12.1)$ \\
\hline S. kloosii & $0(0)$ & $0(0)$ & $0(0)$ & $0(0)$ & $0(0)$ & $1(1.2)$ \\
\hline S. succinus & $0(0)$ & $0(0)$ & $0(0)$ & $0(0)$ & $0(0)$ & $2(2.4)$ \\
\hline Unidentified NAS & $0(0)$ & $0(0)$ & $4(4.8)$ & $6(7.2)$ & $5(6.0)$ & $3(3.6)$ \\
\hline No NAS & $308(77.0)$ & $320(80.0)$ & $4(4.8)$ & $0(0)$ & $4(4.8)$ & $16(19.3)$ \\
\hline Total & 400 & 400 & 83 & 83 & 83 & 83 \\
\hline
\end{tabular}

${ }^{1}$ Quarters were considered positive to a given NAS species before calving if a NAS species was recovered from a single quarter mammary secretion sample at concentration $\geq 100 \mathrm{cfu} / \mathrm{mL}$.

${ }^{2}$ Quarters were considered positive to a given NAS species after calving if the NAS species was recovered from one or both postcalving quarter milk samples (i.e., parallel interpretation) at concentration $\geq 100 \mathrm{cfu} / \mathrm{mL}$. 
S. simulans (Table 2). Among the precalving secretions and postcalving milk samples, Staphylococcus arlettae, S. auricularis, S. equorum, Staphylococcus lentus, S. sciuri, and Staphylococcus vitulinus were identified only in postcalving milk samples.

The odds of having a postcalving IMI with $S$. agnetis [odds ratio $(\mathbf{O R})=193.5 ; 95 \%$ confidence interval $(\mathbf{C I}): 19.2,>999]$, S. chromogenes $(\mathrm{OR}=20.6 ; 95 \%$ CI: $7.4,57.5)$, or $S$. devriesei $(\mathrm{OR}=78.6 ; 95 \%$ CI: $4.2,>999)$ increased when that pathogen was found in precalving secretions. Indeed, 4 quarters were found to have a postcalving $S$. agnetis IMI among the 12 quarters infected precalving (compared with 1 single postcalving infected quarter among the 388 precalving negative quarters). For $S$. chromogenes and $S$. devriesei, the proportions of postcalving positive samples among precalving positive samples was $26 / 59$ and $1 / 6$, respectively (compared with $25 / 341$ and $1 / 394$ for precalving negative quarters).

Having an $S$. chromogenes IMI postcalving $(P<$ 0.01 ) was associated with higher SCS in the second milk sample postcalving (LSM SCS: 3.1; corresponding to a geometric mean SCC of 107,000 cells/mL) when compared with mammary quarters that were culture negative for an IMI at all time points (LSM SCS:1 .15; corresponding to a geometric mean SCC of 28,000 cells $/ \mathrm{mL}$; Table 3$)$. Overall, a high degree of variability among species was found in SCS when comparing the effect of either precalving IMI (Figure 1) or postcalving IMI (Figure 2) on quarter milk SCS at the second postcalving milk sampling.

\section{Body Site Isolation and Its Relationship to Pre- or Postcalving IMI}

A total of 2,304 staphylococcal isolates were recovered from 332 body site samples that originated from the 83 heifers in which a NAS IMI was identified in at least 1 mammary quarter either pre- or postcalving. Due to the replication of a single species on the same body site, 1,532 replicates among the 2,304 isolations of NAS were removed from the data set for the purposes of analysis, leaving 772 occurrences of staphylococcal species isolation from a body site. All $S$. aureus isolations $(\mathrm{n}=14)$ were also removed from the analyses, leaving 758 total occurrences of NAS species isolation from a body site.

At least 1 NAS species was identified from teat skin samples of all 83 heifers. At least 1 NAS species was isolated from $95 \%(79 / 83)$ of inguinal skin samples, $95 \%(79 / 83)$ of muzzle samples, and $80.7 \%(67 / 83)$ of perineum samples (Table 2). The median number of species identified from the teat skin, inguinal skin, muzzle, and perineum was 2 (range: $1-7$ ), 2 (range: $0-5), 2$ (range: $0-7$ ), and 1 (range: $0-5$ ), respectively. Because multiple species could be isolated from a given body site, of the 758 occurrences of NAS species isolation, $214(28 \%), 197(26 \%), 213(28 \%)$, and $134(18 \%)$ were found on the teat skin, inguinal skin, muzzle, and perineum, respectively.

Overall, 17 different NAS species were identified from the body site samples (Table 2). The most common species identified when considering all the body sites

Table 3. Effect of precalving and postcalving quarter IMI status [positive or negative for various non-aureus Staphylococcus (NAS) species] on quarter milk SCS at the second postcalving milk sampling ${ }^{1}$

\begin{tabular}{|c|c|c|c|c|}
\hline \multirow[b]{2}{*}{ IMI status } & \multicolumn{2}{|c|}{ Precalving IMI status } & \multicolumn{2}{|c|}{ Postcalving IMI status } \\
\hline & $\begin{array}{l}\text { Median SCS } \\
\text { LSM estimate }\end{array}$ & $P$-value ${ }^{2}$ & $\begin{array}{l}\text { Median SCS } \\
\text { LSM estimate }\end{array}$ & $P$-value \\
\hline Culture-negative quarters & 1.16 & Referent & 1.15 & Referent \\
\hline S. agnetis & 1.99 & 0.87 & 2.47 & 0.79 \\
\hline S. arlettae & - & - & 1.00 & 1.00 \\
\hline S. auricularis & - & - & 3.10 & 0.99 \\
\hline S. chromogenes & 2.18 & 0.05 & 3.10 & $<0.01$ \\
\hline S. devriesei & 0.71 & 0.99 & - & - \\
\hline S. equorum & - & - & 3.32 & 0.89 \\
\hline S. haemolyticus & 2.29 & 0.97 & 1.00 & 1.00 \\
\hline S. simulans & 3.58 & 0.49 & 3.54 & 0.55 \\
\hline S. vitulinus & - & - & 1.70 & 1.0 \\
\hline S. warneri & 0.90 & 1.0 & 0.70 & 1.0 \\
\hline S. xylosus & 6.80 & 0.71 & 1.94 & 1.0 \\
\hline S. gallinarum & 2.70 & 1.00 & 2.70 & 1.0 \\
\hline Quarter with mixed NAS IMI & 1.80 & 1.00 & 1.36 & 1.0 \\
\hline
\end{tabular}

${ }^{1}$ Estimates were obtained using a linear mixed model with heifer as the random intercept.

${ }^{2} P$-value for comparison of SCS natural logarithm between quarters with a given precalving or postcalving NAS IMI status and culture-negative quarters at precalving mammary secretion sampling or postcalving milk sampling (i.e., culture negative on both postcalving samples). $P$-values were adjusted for multiple comparisons using the Tukey-Kramer method. 
together was S. chromogenes, followed by $S$. xylosus, S. haemolyticus, S. sciuri, and S. devriesei. The most common species identified on the teat skin was $S$. chromogenes, followed by $S$. haemolyticus, $S$. devriesei, and S. xylosus. The most common species identified from inguinal samples was $S$. chromogenes, followed by $S$. haemolyticus, S. xylosus, and S. devriesei. The most common species identified from the muzzle samples was $S$. xylosus, followed by $S$. equorum, S. sciuri, and S. chromogenes. The most common species identified from the perineum was $S$. chromogenes, followed by $S$. haemolyticus, S. xylosus, and S. equorum. Staphylococcus epidermidis, Staphylococcus hominis, Staphylococcus warneri, Staphylococcus gallinarum, and Staphylococcus pasteuri were all associated with either a pre- or postcalving IMI but were not isolated from any of the studied body sites, whereas Staphylococcus saprophyticus, Staphylococcus cohnii, Staphylococcus nepalensis, Staphylococcus succinus, and Staphylococcus kloosii were all identified on body sites but were never isolated from a pre- or postcalving IMI.

Among heifers identified with an NAS IMI in either the pre- or postcalving periods $(\mathrm{n}=83)$, heifers that had $S$. agnetis or $S$. chromogenes identified on the teat skin were at increased odds of having the same NAS species isolated from a precalving IMI (Table 4). Heifers with S. chromogenes identified on the inguinal skin had increased odds of having a precalving S. chromogenes IMI. Additionally, heifers that had S. chromogenes, S. simulans, or S. xylosus identified on the teat

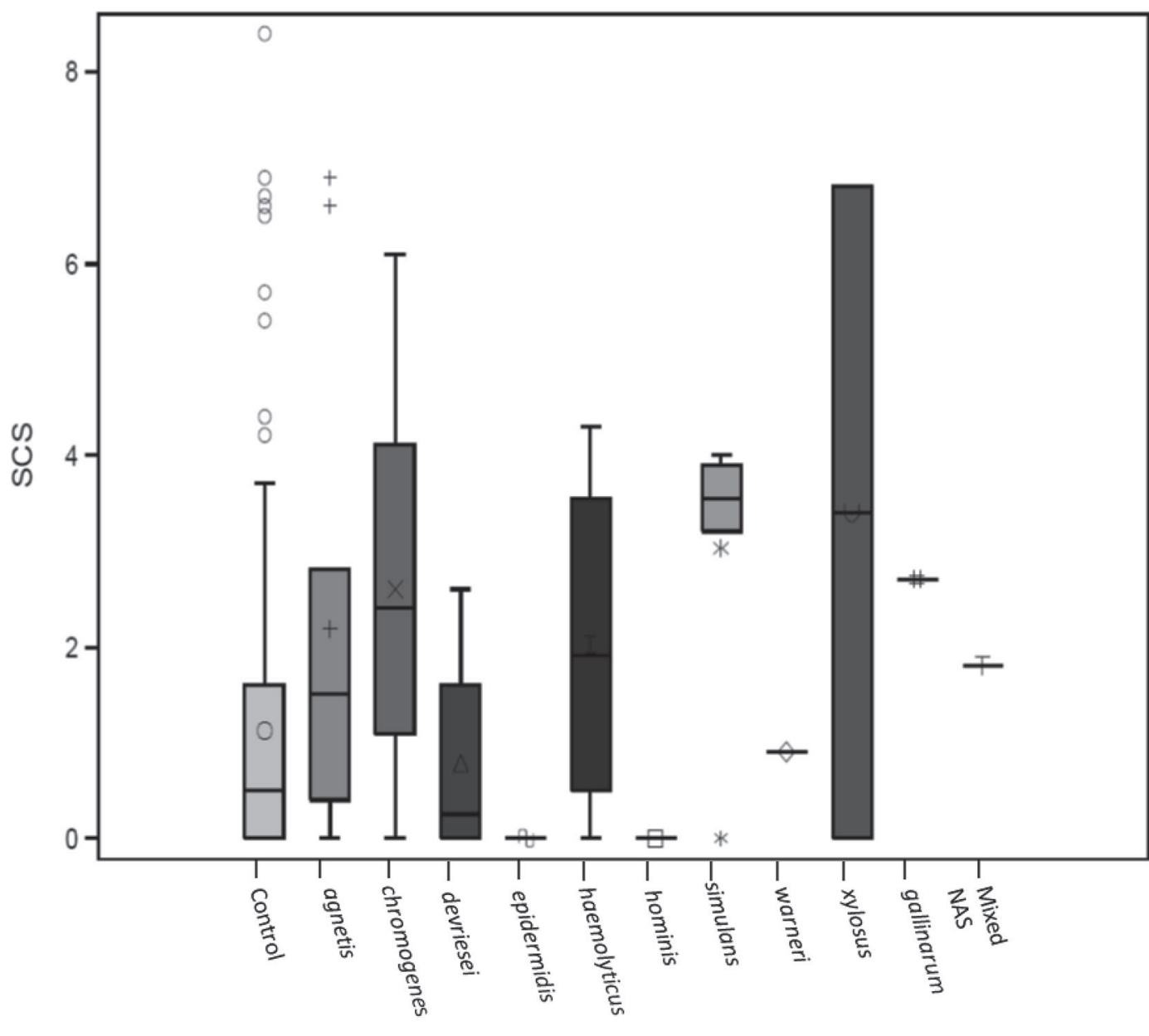

NAS species

Figure 1. Distribution of SCS on second postcalving sampling across precalving quarter non-aureus Staphylococcus (NAS) IMI status. Control = mammary quarters that were culture negative on both postcalving samplings; mixed NAS $=2$ different NAS species identified within 1 quarter at 1 sample point. Each box contains $50 \%$ of the data, the median (line), the 75th quartile, and the 25th quartile. The whiskers are drawn from the box to the most extreme point that is less than or equal to 1.5 times the interquartile range; more extreme observations are represented as a unique symbol for each NAS species or control group. 


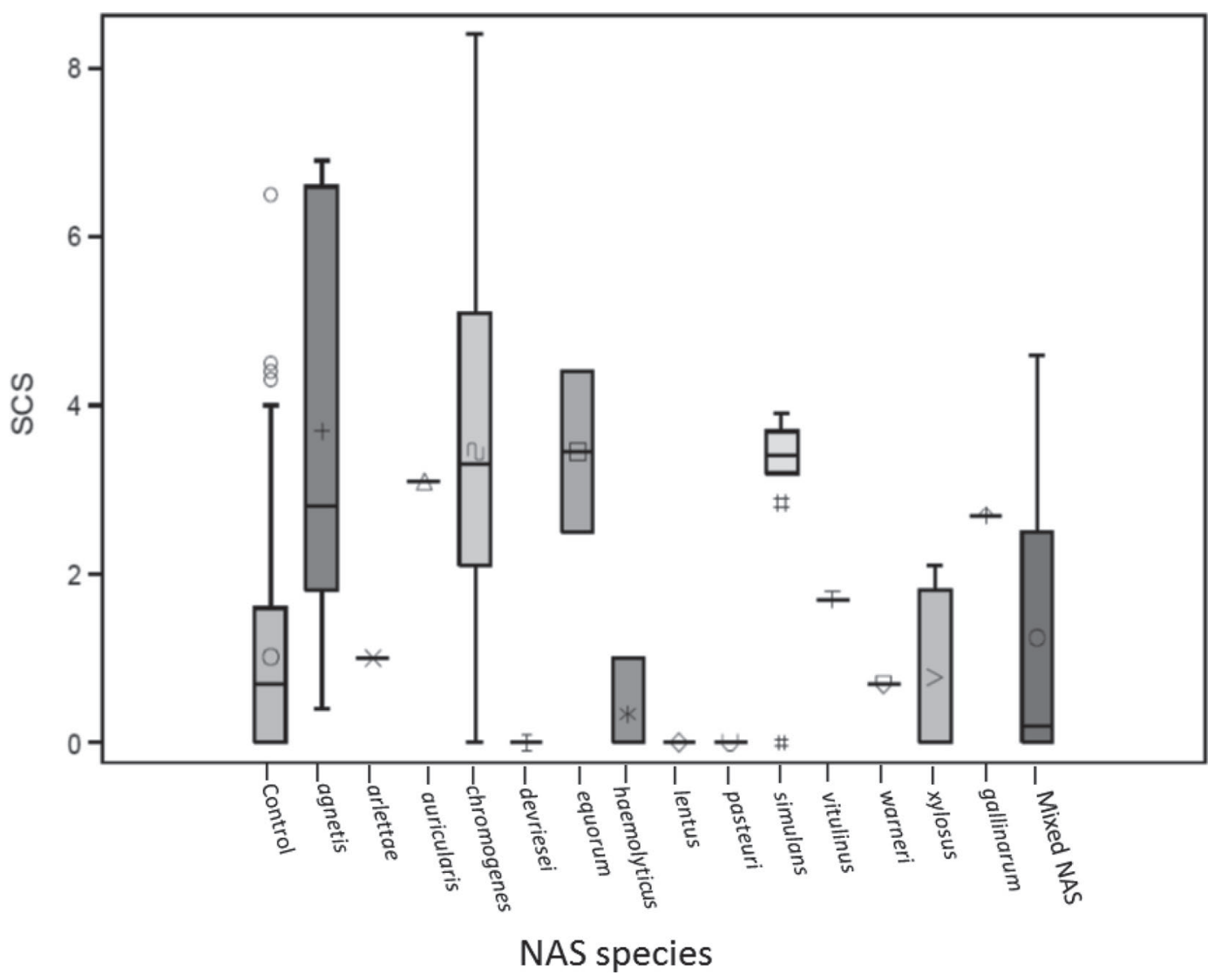

Figure 2. Distribution of SCS on second postcalving sampling across postcalving quarter non-aureus Staphylococcus (NAS) IMI status. Control = mammary quarters that were culture negative on both postcalving samplings; mixed NAS $=2$ different NAS species identified within 1 quarter at 1 sample point. Each box contains $50 \%$ of the data, the median (line), the 75th quartile, and the 25th quartile. The whiskers are drawn from the box to the most extreme point that is less than or equal to 1.5 times the interquartile range; more extreme observations are represented as a unique symbol for each NAS species or control group.

skin had increased odds of having a postcalving IMI with the same NAS species (Table 5). Isolation from the muzzle or perineum was not found to increase odds of a pre- or postcalving IMI for any of the NAS species investigated.

\section{Relationship of Pre- and Postcalving IMI and Body Site Isolation Confirmed by PFGE}

For PFGE strain typing, 44 heifers that had an IMI diagnosed on a precalving mammary secretion sample

Table 4. Effect of having a given non-aureus Staphylococcus (NAS) species isolated from the inguinal skin, teat skin, muzzle, or perineal region on the odds of finding the same NAS species causing a precalving IMI ${ }^{1}$

\begin{tabular}{|c|c|c|c|c|c|c|c|c|}
\hline NAS species ${ }^{2}$ & \multicolumn{2}{|c|}{ Inguinal skin } & \multicolumn{2}{|c|}{ Teat skin } & \multicolumn{2}{|l|}{ Muzzle } & \multicolumn{2}{|l|}{ Perineum } \\
\hline S. agnetis & $1.8(0.19,18.3)$ & 0.59 & $12.7(3.3,48.3)$ & $<0.01$ & -4 & - & - & - \\
\hline S. devriesei & $0.54(0.06,4.7)$ & 0.58 & $1.4(0.27,6.8)$ & 0.72 & $5.6(0.59,52.5)$ & 0.13 & $2.6(0.29,23.4)$ & 0.39 \\
\hline S. haemolyticus & $4.1(0.42,40.2)$ & 0.23 & $1.3(0.18,9.3)$ & 0.81 & - & - & $1.0(0.11,10.2)$ & 0.98 \\
\hline S. simulans & - & - & - & - & - & - & & - \\
\hline
\end{tabular}

${ }^{1}$ Estimates obtained using a generalized mixed model with heifer as the random intercept.

${ }^{2}$ Staphylococcus arlettae, S. auricularis, S. cohnii, S. equorum, S. kloosii, S. lentus, S. nepalensis, S. pasteuri, S. saprophyticus, S. sciuri, S. succinus, and S. vitulinus were not isolated from precalving mammary secretion samples. Staphylococcus epidermidis, S. hominis, S. kloosii, S. pasteuri, S. warneri, and S. gallinarum were not isolated from any body sites.

${ }^{3}$ Odds ratio.

${ }^{4}$ Dash indicates that an association could not be estimated. 
Table 5. Effect of having a given non-aureus Staphylococcus (NAS) species isolated from the inguinal skin, teat skin, muzzle, or perineal region on the odds of finding the same NAS species causing a postcalving IMI ${ }^{1}$

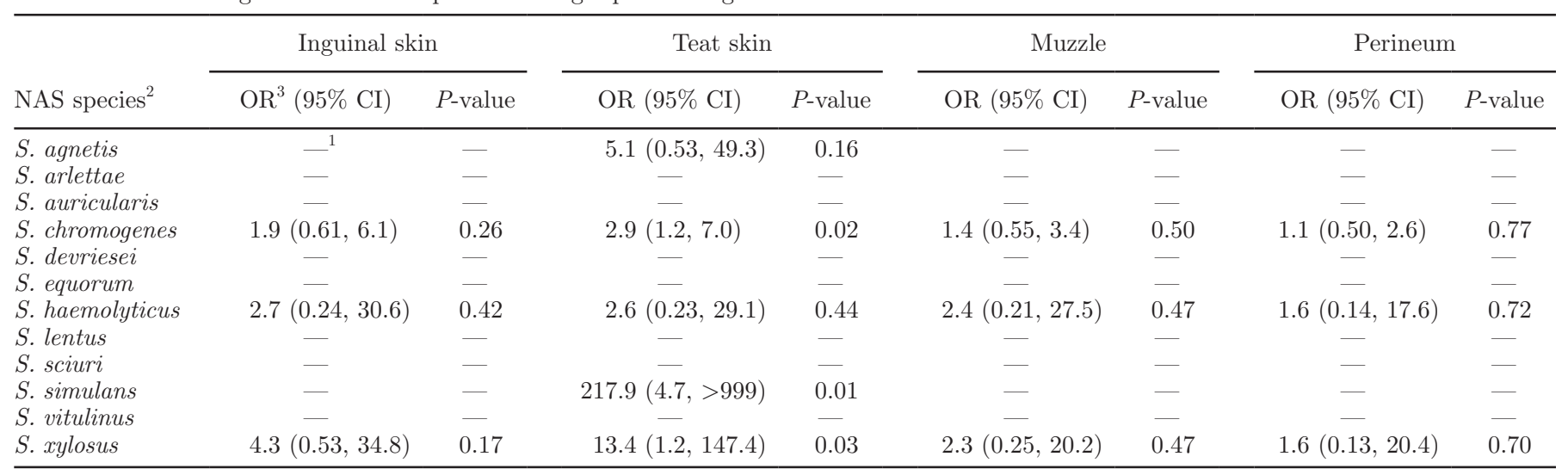

${ }^{1}$ Estimates obtained using a generalized mixed model with heifer as the random intercept.

${ }^{2}$ Staphylococcus cohnii, S. kloosii, S. nepalensis, S. pasteuri, S. saprophyticus, and S. succinus were not isolated from postcalving milk samples. Staphylococcus epidermidis, S. hominis, S. kloosii, S. pasteuri, S. warneri, and S. gallinarum were not isolated from any body sites.

${ }^{3}$ Odds ratio.

${ }^{4}$ Dash indicates that association could not be estimated.

or postcalving milk sample were studied. This included all heifers with an IMI caused by $S$. xylosus, $S$. haemolyticus, S. agnetis, S. simulans, S. devriesei, and S. sciuri and $60 \%$ of heifers with a $S$. chromogenes IMI (Table $5)$. Heifers with an IMI caused by $S$. auricularis, $S$. gallinarum, S. pasteuri, S. lentus, S. vitulinus, S. arlettae, and $S$. equorum were not included because there were no body site isolates of the same species that caused a pre- or postcalving IMI. From the 44 heifers, a total of 551 NAS isolates from body sites and pre- or postcalving IMI were available for PFGE (Table 6). Among these isolates, $40(7.2 \%)$ were classified as untypeable by PFGE based on unreadable banding pattern on repeated analysis, leaving 511 isolates from 42 different heifers with 69 mammary quarter IMI (Table 6).

Overall, within-heifer strain diversity was highest for $S$. chromogenes, with a median number of strains iden- tified per heifer of 6 (range: 2-14). An example of this diversity is illustrated in Figure 3. The median number of strains was 5 (range: 2-10) for S. xylosus, 4 (range: 1-13) for $S$. haemolyticus, 2 (range: 1-3) for $S$. simulans, and 2 (range: $1-2$ ) for $S$. agnetis. Two strains per heifer were identified for all heifers in which $S$. devriesei $(\mathrm{n}=2)$ or $S$. sciuri $(\mathrm{n}=1)$ was isolated. Overall, $44 \%$ of all IMI caused by $S$. chromogenes were found to be the same strain as a body site isolate (Table 7). Body sites in which the same strain of $S$. chromogenes was isolated that caused an IMI included the teat skin, the inguinal skin, and the perineum. On some heifers, the same strain that was associated with an IMI was found in multiple locations, either on both the teat and inguinal or on both the inguinal and perineum. A total of $67 \%$ of S. agnetis strains associated with an IMI were found to be the same strain as an isolate found on the

Table 6. Distribution of isolates subjected to pulsed-field gel electrophoresis (PFGE) strain typing according to non-aureus Staphylococcus (NAS) species and source of isolate ${ }^{1}$

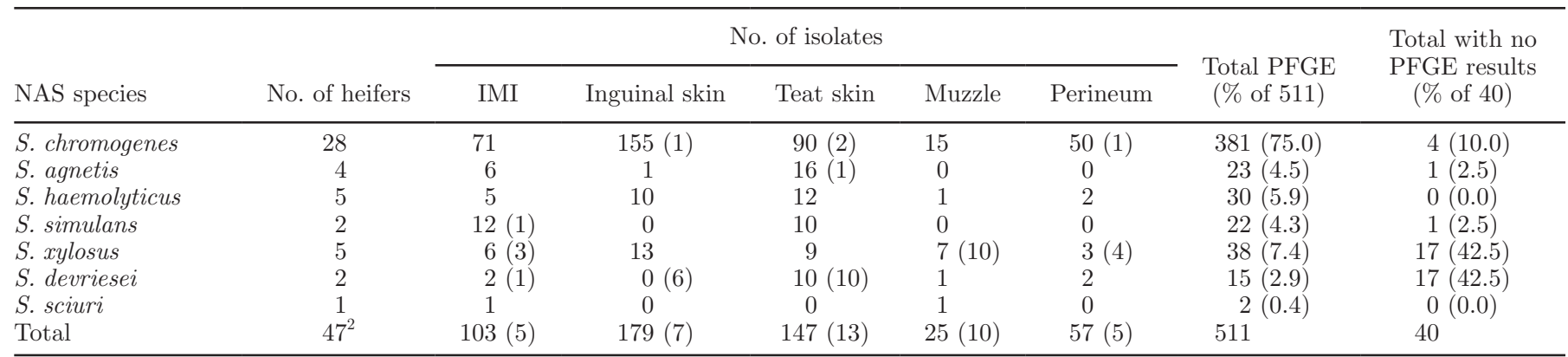

${ }^{1}$ Data are the number of isolates that yielded a PFGE strain type. Parenthetical data in columns 3 through 7 represent the number of isolates within category that were declared untypeable based on no defined banding pattern after repeat analysis.

${ }^{2}$ Total exceeds 44 because 3 heifers had IMI with different species in different mammary quarters. 
teat skin. Of the quarters that had an S. simulans IMI, $40 \%$ were found to be the same strain as those found on the teat skin. A total of $20 \%(1 / 5)$ of $S$. haemolyticus associated with an IMI were found to be the same strain as that found on inguinal skin. One $S$. devriesei isolate that was associated with an IMI was found to be the same strain as that which was found on the teat skin and perineum. For quarters with a $S$. xylosus $(\mathrm{n}=$ 5) or $S$. sciuri $(\mathrm{n}=1)$ IMI, no body site isolates were determined to be the same strain as those found in the mammary gland.

\section{DISCUSSION}

In this longitudinal study, molecular speciation and strain typing were used to evaluate NAS species from IMI and body sites of heifers in the periparturient period. Work by others identified that precalving iso-

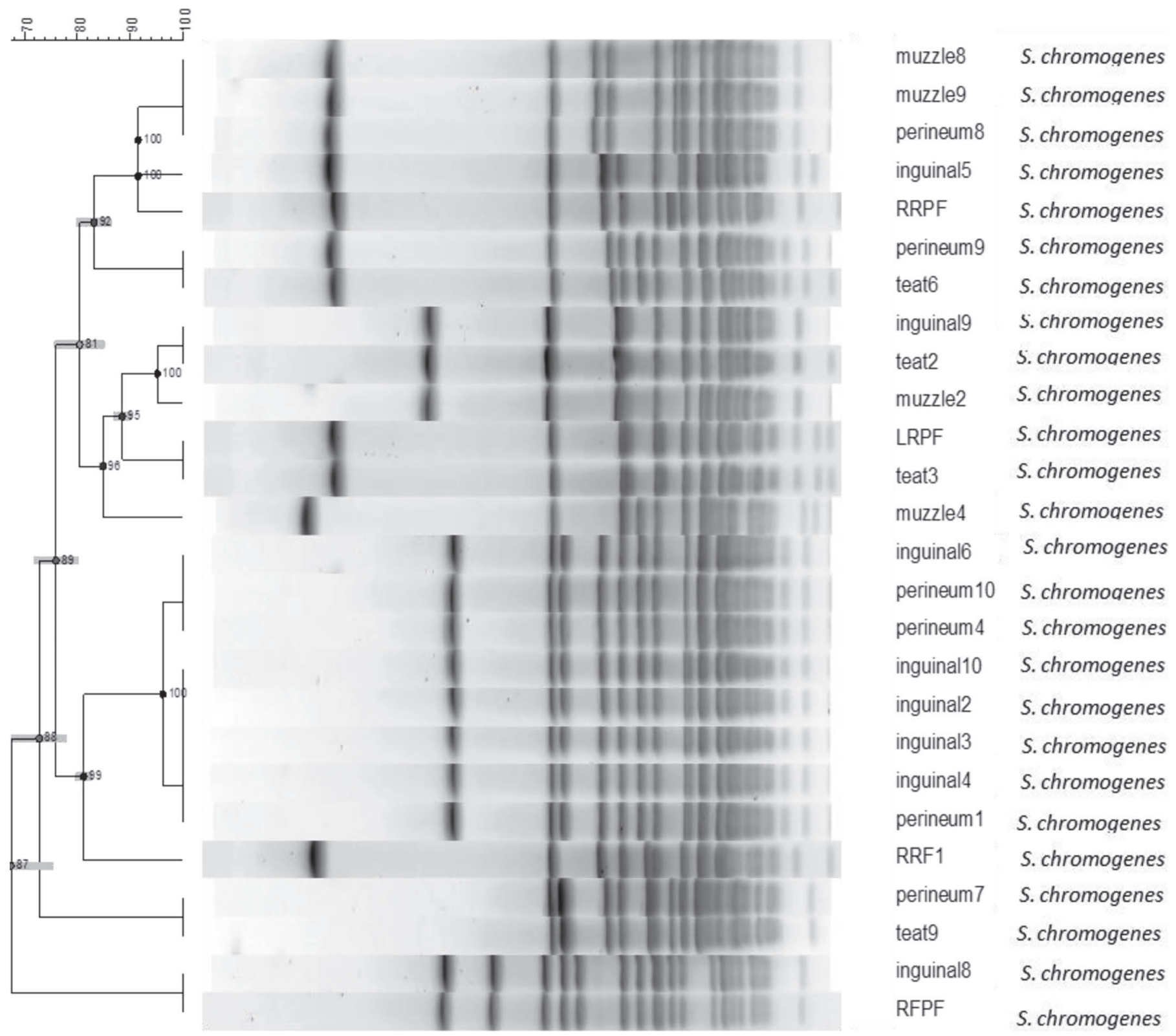

Figure 3. Pulsed-field gel electrophoresis dendogram including all Staphylococcus chromogenes isolates (n $=26)$ from 1 heifer. Within this heifer, 13 different strain types were identified based on a $100 \%$ similarity cut point. The right rear precalving (RRPF) sample was a unique strain, the left rear precalving (LRPF) sample was 100\% identical to the teat3 isolate, the right rear postcalving sample 1 (RRF1) was a unique strain, and the right front precalving sample (RFPF) was $100 \%$ identical to the inguinal 8 isolate. Many of the isolates within body site were replicates of the same strain but some were not, illustrating the need for extensive storage of isolates (in this case, 10 isolated colonies per site) as well as the issues with sensitivity and specificity when studying body site isolation. 


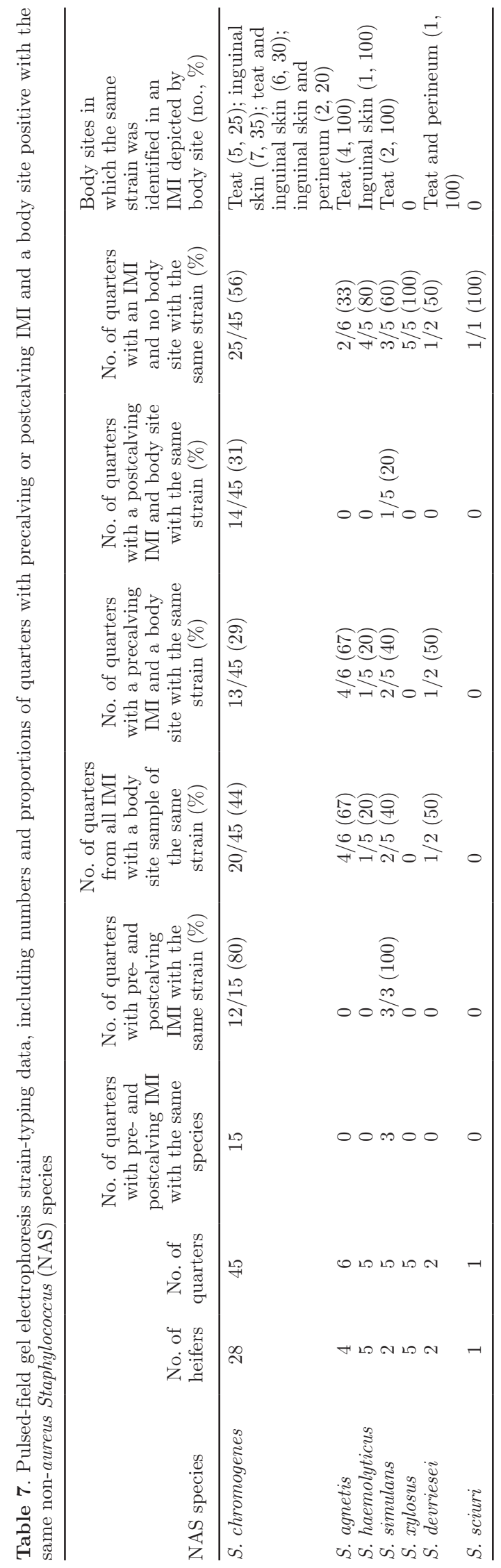

lation of S. chromogenes from the teat end increased the likelihood of $S$. chromogenes IMI in the corresponding quarter at parturition (De Visscher et al., 2016b); however, no subspecies strain typing was conducted in that study. At the species level, for S. chromogenes specifically, similar results were identified in the present study. However, isolation of $S$. chromogenes from the inguinal skin also increased the odds of finding an $S$. chromogenes IMI in the precalving mammary secretion sample. Furthermore, PFGE strain typing identified that in $44 \%$ of $S$. chromogenes IMI evaluated in this study, an $S$. chromogenes isolated from the teat or inguinal skin was found to be $100 \%$ similar to those associated with the periparturient IMI. This finding is similar to what has been found for $S$. aureus (Middleton et al., 2002b). Based on these findings, teat and inguinal skin samples should be included in studies investigating the role of body site isolation in the epidemiology of $S$. chromogenes IMI. However, based on the strain typing done in this study, additional sources other than body sites may also need to be considered when investigating $S$. chromogenes IMI. In other studies, S. chromogenes was rarely identified from parlorassociated niches, including the teat ends (De Visscher et al., 2014), or the barn environment (Piessens et al., 2011), suggesting the potential of host adaptation and the possibility of cow-to-cow transmission (De Visscher et al., 2014). Although hypothesized, previous straintyping studies have provided only limited support for contagious transmission due to considerable strain heterogeneity (Zadoks et al., 2011), which was also noted in this study.

Isolation of $S$. simulans and $S$. xylosus from the teat skin precalving also increased the odds of finding that same species associated with a NAS IMI postcalving. Strain typing found that when the same strain of $S$. simulans was isolated from a body site as that associated with an IMI, it was always found on the teat skin. Conversely, no body site isolates were found to be similar to the isolates associated with an IMI in the case of $S$. xylosus. Therefore, although $S$. xylosus can be isolated from the teat skin and may play a role, other factors are likely involved with the development of an S. xylosus IMI, such as contamination of the postcalving environment, as previously described (Piessens et al., 2011).

Precalving IMI with $S$. agnetis, $S$. chromogenes, or $S$. devriesei significantly increased the odds of having an IMI postcalving with the same NAS species. One study identified S. chromogenes and S. hyicus to be the most prevalent bacterial species isolated from nonpregnant and primigravid heifers' mammary gland secretions (Trinidad et al., 1990). At the time of that study, $S$. agnetis (Taponen et al., 2012) and S. devriesei (Su- 
pré et al., 2010) had not been classified and therefore were not identified. Unlike the study by Trinidad et al. (1990), S. hyicus was not identified in the present study. However, because $S$. agnetis and S. hyicus are phenotypically indistinguishable (Taponen et al., 2012), it is very likely that isolates previously reported as $S$. hyicus were truly $S$. agnetis. Overall, because of the effect a precalving IMI can have on postcalving IMI status, if interventions or prevention strategies are pursued for these NAS species in the future, targeting interventions in the precalving period will likely be needed.

Although NAS species are considered to be teat skin opportunists, the results of the present study showed that not all species commonly found on the skin of the heifer are commonly associated with IMI. For example, S. saprophyticus, S. cohnii, S. sciuri, and S. nepalensis were commonly found on body sites but were rarely, if ever, found to be associated with IMI. Furthermore, a few species that were rarely associated with IMI were never identified on a body site, including $S$. epidermidis, S. hominis, S. warneri, S. gallinarum, and S. pasteuri. Although $S$. epidermidis is often identified as one of the more prevalent NAS species associated with IMI (Thorberg et al., 2009; Piessens et al., 2011; Fry et al., 2014) and found in bulk tank milk samples (De Visscher et al., 2017), in general this species is more common in older cows than heifers (Thorberg et al., 2009). Furthermore, others reported that S. epidermidis was rarely found on the teat ends of precalving heifers (De Visscher et al., 2016b; Adkins et al., 2018). In contrast, S. epidermidis has been found to be prevalent on human skin, and it has been postulated that when it is found in cases of IMI, it may have been transmitted from milkers' hands to cows (Thorberg et al., 2006).

Overall, a diverse population of staphylococcal species was identified to be associated with IMI and body sites. For body sites specifically, 17 different NAS species were identified. Evaluation of the teat end microbiome has demonstrated that NAS species are the most frequently isolated and most commonly present species, with only minor occurrences of other genera (Braem et al., 2013). The microbiome of other body sites, including the inguinal region, muzzle, and perineum, have not been previously evaluated. In the present study, several samples were identified as NAS negative, with the majority of negatives being samples from the perineum. It is possible that these samples were not truly NAS negative, as overgrowth of other bacterial species may have prevented the identification of colonies of interest. Using culture-independent methods may allow full assessment of the NAS populations in these samples and help determine the interactions between different bacterial populations. Future studies using metagenomics to evaluate the microbiome of these body sites may help further characterize the interactions of body site isolation and IMI.

For many of the dominant species identified, a high level of strain diversity, based on PFGE, was found among isolates collected from body site samples and IMI from a single heifer. On one heifer up to 14 different strains of $S$. chromogenes were identified, and on another heifer up to 13 different strains of S. haemolyticus were found. This high level of strain diversity may make it very challenging to truly determine the origin of an IMI if only a few isolates of a given species are strain typed and may be the reason why only $44 \%$ of all $S$. chromogenes IMI were found to be the same as an isolate that originated from a body site, as some strains may have been missed. However, it is also possible that the majority of $S$. chromogenes IMI are not related to a body site isolate and originate from other locations. Additionally, the high level of strain diversity may be related to the stringent cut-off of $100 \%$ similarity used in the present study. Other studies have used a 70 to $84 \%$ similarity value as a cut point to define $S$. aureus strain types (Boerema et al., 2006; Du et al., 2014). Although this will allow more grouping of isolates, it will also potentially group isolates that may not be epidemiologically related. A $100 \%$ similarity cut point was used so that isolates with genetically indistinguishable restriction patterns would be considered the same strain type and isolates that are closely related, which may have a single genetic alteration resulting in 2 or 3 band differences when examined by PFGE, would be considered a different strain (Tenover et al., 1995). Although PFGE currently is considered the gold standard for strain typing of staphylococcal species (Bannerman et al., 1995; Salipante et al., 2015), wholegenome sequencing has demonstrated that PFGE is prone to some false-positive and false-negative results. Therefore, as whole-genome sequencing becomes more economically feasible for characterizing large numbers of isolates, it will become the new gold standard (Salipante et al., 2015). Regardless, a cheaper, faster, and accurate strain-typing method would be beneficial to the efficient study of NAS subspecies diversity on dairy farms.

Overall, the MALDI-TOF validation confirmed that this method is a quick, easy, and accurate way to speciate many of the staphylococcal species isolated from bovine samples, which is consistent with other recent reports (Tomazi et al., 2014; Cameron et al., 2017, 2018). After adding 3 isolates to the University of Missouri laboratory custom database, MALDI-TOF correctly identified $96.1 \%$ of the validation isolates. Also, MALDI-TOF was not found to misclassify isolates. However, for some NAS species, such as S. auricularis, a large percentage of the isolates were categorized as 
unidentifiable (Table 1). One downfall of this method is that it is unable to differentiate $S$. hyicus and $S$. agnetis. Even after adding an $S$. agnetis isolate to the custom database, MALDI-TOF could not differentiate these 2 species. Therefore, this method should not be used to speciate $S$. hyicus and $S$. agnetis isolates. These species can easily be differentiated using tuf sequencing or aroD multiplex PCR (Adkins et al., 2017).

Storage time at $-20^{\circ} \mathrm{C}$ could have affected the number of truly negative and truly positive samples; however, the effect was expected to be minimal. Freezing has been associated with an increase in the number of samples positive for NAS species (Schukken et al., 1989). The IMI definition of $\geq 100 \mathrm{cfu} / \mathrm{mL}$ was selected for this study to increase the sensitivity of detecting an IMI, which according to Dohoo et al. (2011a) maximizes sensitivity of detecting an NAS IMI at $80.9 \%$. A pitfall of the increased sensitivity is a lower specificity, which at the selected threshold of $\geq 100 \mathrm{cfu} / \mathrm{mL}$ was reported to be $86.7 \%$ (Dohoo et al., 2011a). Therefore, both false positives and false negatives are expected with the definitions of IMI used in the present study.

Although S. chromogenes IMI was found to be associated with an increase in SCC in early lactation compared with culture-negative quarters, false positives may explain why some of the SCC for prevalent species, specifically $S$. simulans and $S$. xylosus, were not found to be different from culture-negative quarters as previously reported by others (Tomazi et al., 2015). Furthermore, some culture-negative control quarters had a relatively high SCC, which could be due to the low sensitivity of bacterial culture. The overall high degree of variability in milk SCC within a given species has been previously reported (Fry et al., 2014), which may be related to a relatively low number of isolates within some of the NAS species in the present study, differences in pathogenicity between bacterial strains within species, or cow-level factors.

One limitation of this study was that it was conducted on only 1 farm, and hence results may not be generalizable to other farms. Further, specific risk factors for NAS IMI or body site isolation could not be assessed. Although this is a limitation, some of the results are corroborated by previous studies (White et al., 1989; De Visscher et al., 2016b). For example, the most common species identified from the teat skin samples were S. chromogenes, S. haemolyticus, and S. devriesei, which is similar to what has been recently reported on heifers from 13 commercial dairies in Belgium (De Visscher et al., 2016b). Furthermore, 3 of the more common species found to be associated with IMI postcalving were $S$. chromogenes, S. xylosus, and S. simulans, which were also found to be among the more common species identified in quarter milk of heifers at parturition from
13 different dairy herds in Belgium (De Visscher et al., 2016a).

Finally, it has been previously reported that the use of strain typing to relate body site isolation, specifically teat end isolation, to IMI may be confounded by the teat end becoming contaminated with staphylococciladen milk before teat skin sample collection (Leroy et al., 2015). However, in the present study all body site samples were collected first, and the heifers had never been milked at the time of body site sample collection. Therefore, the risk of this contamination by isolates from within the mammary gland was predicted to be very low in the current study. However, it is possible that the mammary secretion sample could have become contaminated by the NAS species on the teat skin or streak canal during collection. The skin was, however, vigorously cleaned with both a teat disinfectant and isopropyl alcohol before mammary quarter secretion or milk sample collection.

\section{CONCLUSIONS}

Staphylococcus chromogenes, S. agnetis, and S. simulans were the most common species identified in precalving mammary secretions, whereas S. chromogenes, S. xylosus, and S. agnetis were the most common species found in postcalving milk samples. The most common species identified on body sites were $S$. chromogenes, $S$. xylosus, and S. haemolyticus. Mammary quarters that had a precalving mammary secretion culture positive for S. agnetis, S. chromogenes, and S. devriesei had significantly increased odds of having an IMI with the same species postcalving. An S. chromogenes IMI postcalving was associated with higher SCC after calving when compared with culture-negative quarters. Heifers that had S. agnetis or S. chromogenes isolated from the teat skin had increased odds of having the same species found in the precalving mammary secretions. Heifers with $S$. chromogenes isolated from the inguinal region had increased odds of having S. chromogenes isolated from the precalving mammary secretions. Heifers that had S. chromogenes, S. simulans, or S. xylosus isolated from the teat skin precalving had increased odds of having an IMI with the same species postcalving.

Based on PFGE, a high level of strain diversity was found among isolates collected from body site samples. Overall, $44 \%$ of all heifers with a $S$. chromogenes IMI around the time of parturition were found to have the same strain isolated from a body site, including teat skin, inguinal skin, and the perineum. Conversely, no body site isolates were found to be the same strain as isolates from an IMI caused by $S$. xylosus. When strain typing was applied to understanding the relationship between IMI pre- and postcalving and body 
site isolation, the picture was less clear than when the data were evaluated at just the species level. Study of these relationships at the subspecies level demonstrated that only some of the heifers that had an IMI with a given species had the same exact strain of that species isolated from a body site. These findings illustrate the need for subspecies identification of bacterial isolates to truly understand the epidemiology of staphylococcal IMI and the relationship of body site isolation.

\section{ACKNOWLEDGMENTS}

This project was partially funded by USDA National Institute of Food and Agriculture project numbers MOV-2-FF50 and AH4209231242. We thank the many University of Missouri (Columbia) students who helped with this project, including Alicia Finger, Rachel Webster, Travis Cline, Nicole Walljasper, and Grant Voelker. We also thank the University of Missouri dairy farm staff for all their assistance, especially Eric Adkins and John Denbigh. Finally, we thank Julie Holle (University of Missouri Veterinary Health Center) for technical assistance.

\section{REFERENCES}

Adkins, P. R. F., S. Dufour, J. N. Spain, M. J. Calcutt, T. J. Reilly, G. C. Stewart, and J. R. Middleton. 2018. Cross-sectional study to identify staphylococcal species isolated from teat and inguinal skin of different-aged dairy heifers. J. Dairy Sci. 101:3213-3225. https://doi.org/10.3168/jds.2017-13974.

Adkins, P. R. F., J. R. Middleton, M. J. Calcutt, G. C. Stewart, and L. K. Fox. 2017. Speciation and strain-typing of Staphylococcus agnetis and Staphylococcus hyicus isolated from bovine milk using a novel multiplex PCR and pulsed-field gel electrophoresis. J. Clin. Microbiol. 55:1778-1788.

Archer, S. C., F. Mc Coy, W. Wapenaar, and M. J. Green. 2013. Association between somatic cell count early in the first lactation and the longevity of Irish dairy cows. J. Dairy Sci. 96:2939-2950.

Bannerman, T. L., G. A. Hancock, F. C. Tenover, and J. M. Miller. 1995. Pulsed-field gel electrophoresis as a replacement for bacteriophage typing of Staphylococcus aureus. J. Clin. Microbiol. $33: 551-555$.

Boerema, J. A., R. Clemens, and G. Brightwell. 2006. Evaluation of molecular methods to determine enterotoxigenic status and molecular genotype of bovine, ovine, human and food isolates of Staphylococcus aureus. Int. J. Food Microbiol. 107:192-201.

Braem, G., S. De Vliegher, B. Verbist, V. Piessens, E. Van Coillie, L. De Vuyst, and F. Leroy. 2013. Unraveling the microbiota of teat apices of clinically healthy lactating dairy cows, with special emphasis on coagulase-negative staphylococci. J. Dairy Sci. 96:1499-1510.

Braem, G., B. Stijlemans, W. Van Haken, S. De Vliegher, L. De Vuyst, and F. Leroy. 2014. Antibacterial activities of coagulase-negative staphylococci from bovine teat apex skin and their inhibitory effect on mastitis-related pathogens. J. Appl. Microbiol. 116:1084-1093.

Cameron, M., H. W. Barkema, J. De Buck, S. De Vliegher, M. Chaffer, J. Lewis, and G. P. Keefe. 2017. Identification of bovine-associated coagulase-negative staphylococci by matrix-assisted laser desorption/ionization time-of-flight mass spectrometry using a direct transfer protocol. J. Dairy Sci. 100:2137-2147.

Cameron, M., J. Perry, J. R. Middleton, M. Chaffer, J. Lewis, and G. P. Keefe. 2018. Short communication: Evaluation of MALDI-TOF mass spectrometry and a custom reference spectra expanded database for the identification of bovine-associated coagulase-negative staphylococci. J. Dairy Sci. 101:590-595.

Coffey, E. M., W. E. Vinson, and R. E. Pearson. 1986. Somatic cell counts and infection rates for cows of varying somatic cell count in initial test of first lactation. J. Dairy Sci. 69:552-555.

De Visscher, A., S. Piepers, F. Haesebrouck, and S. De Vliegher. 2016a. Intramammary infection with coagulase-negative staphylococci at parturition: Species-specific prevalence, risk factors, and effect on udder health. J. Dairy Sci. 99:6457-6469.

De Visscher, A., S. Piepers, F. Haesebrouck, and S. De Vliegher. 2016b. Teat apex colonization with coagulase-negative Staphylococcus species before parturition: Distribution and species-specific risk factors. J. Dairy Sci. 99:1427-1439.

De Visscher, A., S. Piepers, F. Haesebrouck, K. Supré, and S. De Vliegher. 2017. Coagulase-negative Staphylococcus species in bulk milk: Prevalence, distribution, and associated subgroup- and species-specific risk factors. J. Dairy Sci. 100:629-642.

De Visscher, A., K. Supré, F. Haesebrouck, R. N. Zadoks, V. Piessens, E. Van Coillie, S. Piepers, and S. De Vliegher. 2014. Further evidence for the existence of environmental and host-associated species of coagulase-negative staphylococci in dairy cattle. Vet. Microbiol. 172:466-474.

De Vliegher, S., H. W. Barkema, G. Opsomer, A. de Kruif, and L. Duchateau. 2005a. Association between somatic cell count in early lactation and culling of dairy heifers using cox frailty models. J. Dairy Sci. 88:560-568.

De Vliegher, S., H. W. Barkema, H. Stryhn, G. Opsomer, and A. de Kruif. 2004a. Impact of early lactation somatic cell count in heifers on somatic cell counts over the first lactation. J. Dairy Sci. $87: 3672-3682$.

De Vliegher, S., H. W. Barkema, H. Stryhn, G. Opsomer, and A. de Kruif. 2005b. Impact of early lactation somatic cell count in heifers on milk yield over the first lactation. J. Dairy Sci. 88:938-947.

De Vliegher, S., L. K. Fox, S. Piepers, S. McDougall, and H. W. Barkema. 2012. Invited review: Mastitis in dairy heifers: Nature of the disease, potential impact, prevention, and control. J. Dairy Sci. 95:1025-1040.

De Vliegher, S., H. Laevens, L. A. Devriese, G. Opsomer, J. L. Leroy, H. W. Barkema, and A. de Kruif. 2003. Pre-calving teat apex colonization with Staphylococcus chromogenes in dairy heifers is associated with low somatic cell count in early lactation. Vet. Microbiol. 92:245-252.

De Vliegher, S., G. Opsomer, A. Vanrolleghem, L. A. Devriese, O. C. Sampimon, J. Sol, H. W. Barkema, F. Haesebrouck, and A. de Kruif. 2004b. In vitro growth inhibition of major mastitis pathogens by Staphylococcus chromogenes originating from teat apices of dairy heifers. Vet. Microbiol. 101:215-221.

Devriese, L. A., and H. De Keyser. 1980. Prevalence of different species of coagulase-negative staphylococci on teats and in milk samples from dairy cows. J. Dairy Res. 47:155-158.

Devriese, L. A., K. H. Schleifer, and G. O. Adegoke. 1985. Identification of coagulase-negative staphylococci from farm animals. J. Appl. Bacteriol. 58:45-55.

Dohoo, I., S. Andersen, R. Digwell, K. Hand, D. Kelton, K. Leslie, Y. Schukken, and S. Godden. 2011b. Diagnosing intramammary infections: Comparison of multiple versus single quarter milk samples for the identification of intramammary infections in lactating dairy cows. J. Dairy Sci. 94:5515-5522.

Dohoo, I. R., J. Smith, S. Andersen, D. F. Kelton, and S. Godden. 2011a. Diagnosing intramammary infections: Evaluation of definitions based on a single milk sample. J. Dairy Sci. 94:250-261.

Drancourt, M., and D. Raoult. 2002. rpoB gene sequence-based identification of Staphylococcus species. J. Clin. Microbiol. 40:1333-1338.

Du, X. F., M. Xiao, H. Y. Liang, Z. Sun, Y. H. Jiang, G. Y. Chen, X. Y. Meng, G. L. Zou, L. Zhang, Y. L. Liu, H. Zhang, H. L. Sun, X. F. Jiang, and Y. C. Xu. 2014. An improved MLVF method and its comparison with traditional MLVF, spa typing, MLST/SCCmec and PFGE for the typing of methicillin-resistant Staphylococcus aureus. Int. J. Mol. Sci. 15:725-742. 
Fox, L. K. 2009. Prevalence, incidence and risk factors of heifer mastitis. Vet. Microbiol. 134:82-88.

Fox, L. K., S. T. Chester, J. W. Hallberg, S. C. Nickerson, J. W. Pankey, and L. D. Weaver. 1995. Survey of intramammary infections in dairy heifers at breeding age and first parturition. J. Dairy Sci. 78:1619-1628.

Fry, P. R., J. R. Middleton, S. Dufour, J. Perry, D. Scholl, and I. Dohoo. 2014. Association of coagulase-negative staphylococcal species, mammary quarter milk somatic cell count, and persistence of intramammary infection in dairy cattle. J. Dairy Sci. 97:4876-4885.

Hoet, A. E., A. Johnson, R. C. Nava-Hoet, S. Bateman, A. Hillier, J. Dyce, W. A. Gebreyes, and T. E. Wittum. 2011. Environmental methicillin-resistant Staphylococcus aureus in a veterinary teaching hospital during a nonoutbreak period. Vector Borne Zoonotic Dis. 11:609-615.

Hwang, S. M., M. S. Kim, K. U. Park, J. Song, and E. C. Kim. 2011. tuf gene sequence analysis has greater discriminatory power than 16S rRNA sequence analysis in identification of clinical isolates of coagulase-negative staphylococci. J. Clin. Microbiol. 49:4142-4149.

Leroy, F., E. Van Coillie, G. Braem, V. Piessens, B. Verbist, L. De Vuyst, and S. De Vliegher. 2015. Subtyping of Staphylococcus haemolyticus isolates from milk and corresponding teat apices to verify the potential teat-skin origin of intramammary infections in dairy cows. J. Dairy Sci. 98:7893-7898.

Mellmann, A., K. Becker, C. von Eiff, U. Keckevoet, P. Schumann, and D. Harmsen. 2006. Sequencing and staphylococci identification. Emerg. Infect. Dis. 12:333-336.

Middleton, J. R., L. K. Fox, J. M. Gay, J. W. Tyler, and T. E. Besser. 2002a. Influence of Staphylococcus aureus strain-type on mammary quarter milk somatic cell count and $N$-acetyl- $\beta$-D-glucosaminidase activity in cattle from eight dairies. J. Dairy Sci. 85:1133-1140.

Middleton, J. R., L. K. Fox, J. M. Gay, J. W. Tyler, and T. E. Besser 2002b. Use of pulsed-field gel electrophoresis for detecting differences in Staphylococcus aureus strain populations between dairy herds with different cattle importation practices. Epidemiol. Infect. 129:387-395.

Middleton, J. R., L. K. Fox, G. Pighetti, and C. Petersson-Wolfe. 2017. Laboratory Handbook on Bovine Mastitis. National Mastitis Council, New Prague, MN.

Piepers, S., G. Opsomer, H. W. Barkema, A. de Kruif, and S. De Vliegher. 2010. Heifers infected with coagulase-negative staphylococci in early lactation have fewer cases of clinical mastitis and higher milk production in their first lactation than noninfected heifers. J. Dairy Sci. 93:2014-2024.

Piessens, V., E. Van Coillie, B. Verbist, K. Supré, G. Braem, A. Van Nuffel, L. De Vuyst, M. Heyndrickx, and S. De Vliegher. 2011. Distribution of coagulase-negative Staphylococcus species from milk and environment of dairy cows differs between herds. J. Dairy Sci. 94:2933-2944.

Rajala-Schultz, P. J., A. H. Torres, F. J. Degraves, W. A. Gebreyes, and P. Patchanee. 2009. Antimicrobial resistance and genotypic characterization of coagulase-negative staphylococci over the dry period. Vet. Microbiol. 134:55-64.

Roberson, J. R., L. K. Fox, D. D. Hancock, J. M. Gay, and T. E. Besser. 1994. Ecology of Staphylococcus aureus isolated from various sites on dairy farms. J. Dairy Sci. 77:3354-3364.

Salipante, S. J., D. J. SenGupta, L. A. Cummings, T. A. Land, D. R. Hoogestraat, and B. T. Cookson. 2015. Application of wholegenome sequencing for bacterial strain typing in molecular epidemiology. J. Clin. Microbiol. 53:1072-1079.

Sargeant, J. M., K. E. Leslie, J. E. Shirley, B. J. Pullrabek, and G. H. Lim. 2001. Sensitivity and specificity of somatic cell count and California mastitis test for identifying intramammary infection in early lactation. J. Dairy Sci. 84:2018-2024.
Schukken, Y. H., J. A. H. Smit, F. J. Grommers, D. Vandegeer, and A. Brand. 1989. Effect of freezing on bacteriologic culturing of mastitis milk samples. J. Dairy Sci. 72:1900-1906.

Supré, K., S. De Vliegher, I. Cleenwerck, K. Engelbeen, S. Van Trappen, S. Piepers, O. C. Sampimon, R. N. Zadoks, P. De Vos, and F. Haesebrouck. 2010. Staphylococcus devriesei sp. nov., isolated from teat apices and milk of dairy cows. Int. J. Syst. Evol. Microbiol. 60:2739-2744.

Supré, K., F. Haesebrouck, R. N. Zadoks, M. Vaneechoutte, S. Piepers, and S. De Vliegher. 2011. Some coagulase-negative Staphylococcus species affect udder health more than others. J. Dairy Sci. 94:2329-2340

Taponen, S., J. Bjorkroth, and S. Pyörälä. 2008. Coagulase-negative staphylococci isolated from bovine extramammary sites and intramammary infections in a single dairy herd. J. Dairy Res. 75:422429

Taponen, S., K. Supré, V. Piessens, E. Van Coillie, S. De Vliegher, and J. M. Koort. 2012. Staphylococcus agnetis sp. nov., a coagulasevariable species from bovine subclinical and mild clinical mastitis. Int. J. Syst. Evol. Microbiol. 62:61-65.

Tenover, F. C., R. D. Arbeit, R. V. Goering, P. A. Mickelsen, B. E. Murray, D. H. Persing, and B. Swaminathan. 1995. Interpreting chromosomal DNA restriction patterns produced by pulsed-field gel electrophoresis: Criteria for bacterial strain typing. J. Clin. Microbiol. 33:2233-2239.

Thorberg, B. M., M. L. Danielsson-Tham, U. Emanuelson, and K. Persson Waller. 2009. Bovine subclinical mastitis caused by different types of coagulase-negative staphylococci. J. Dairy Sci. 92:4962-4970.

Thorberg, B. M., I. Kuhn, F. M. Aarestrup, B. Brandstrom, P. Jonsson, and M. L. Danielsson-Tham. 2006. Pheno- and genotyping of Staphylococcus epidermidis isolated from bovine milk and human skin. Vet. Microbiol. 115:163-172.

Tomazi, T., J. L. Goncalves, J. R. Barreiro, M. A. Arcari, and M. V. dos Santos. 2015. Bovine subclinical intramammary infection caused by coagulase-negative staphylococci increases somatic cell count but has no effect on milk yield or composition. J. Dairy Sci. 98:3071-3078

Tomazi, T., J. L. Goncalves, J. R. Barreiro, P. A. de Campos Braga, L. F. Prada e Silva, M. N. Eberlin, and M. V. dos Santos. 2014. Identification of coagulase-negative staphylococci from bovine intramammary infection by matrix-assisted laser desorption ionizationtime of flight mass spectrometry. J. Clin. Microbiol. 52:1658-1663.

Trinidad, P., S. C. Nickerson, and T. K. Alley. 1990. Prevalence of intramammary infection and teat canal colonization in unbred and primigravid dairy heifers. J. Dairy Sci. 73:107-114.

van Balen, J., C. Kelley, R. C. Nava-Hoet, S. Bateman, A. Hillier, J. Dyce, T. E. Wittum, and A. E. Hoet. 2013. Presence, distribution, and molecular epidemiology of methicillin-resistant Staphylococcus aureus in a small animal teaching hospital: A year-long active surveillance targeting dogs and their environment. Vector Borne Zoonotic Dis. 13:299-311.

White, D. G., R. J. Harmon, J. E. Matos, and B. E. Langlois. 1989. Isolation and identification of coagulase-negative Staphylococcus species from bovine body sites and streak canals of nulliparous heifers. J. Dairy Sci. 72:1886-1892.

Zadoks, R. N., J. R. Middleton, S. McDougall, J. Katholm, and Y. H. Schukken. 2011. Molecular epidemiology of mastitis pathogens of dairy cattle and comparative relevance to humans. J. Mammary Gland Biol. Neoplasia 16:357-372.

Zadoks, R. N., and J. L. Watts. 2009. Species identification of coagulase-negative staphylococci: Genotyping is superior to phenotype. Vet. Microbiol. 134:20-28. 